\title{
PEMANFAATAN HASIL PEMBAKARAN LIMBAH CANGKANG KELAPA SAWIT SEBAGAI BAHAN PENGGANTI PASIR PADA PEMBUATAN BETON NORMAL
}

\author{
Fauzi Rahman ${ }^{\left(1^{*}\right)}$, Fathurrahman $^{(2)}$ \\ Program Studi Teknik Sipil Universitas Lambung Mangkurat \\ ${ }^{*}$ Email: frahmanktb@yahoo.co.id
}

\begin{abstract}
ABSTRAK
Berdasarkan data statistik perkebunan Indonesia pada tahun 2015 total luas areal perkebunan kelapa sawit di Kalimantan mencapai 3,47 juta Ha dengan produksi 8,12 juta ton per tahun. Dengan besarnya angka produksi tersebut tentu saja limbah yang dihasilkan juga banyak baik berupa limbah padat atau limbah cair. Limbah padat itu berupa tandan buah segar dan cangkang kelapa sawit. Saat ini limbah padat berupa cangkang kelapa sawit dimanfaatkan sebagai bahan bakar boiler untuk mesin penggilingan minyak sawit dan sebagai bahan bakar mesin gasifikasi untuk menghasilkan gas bakar yang dapat digunakan untuk berbagai keperluan energi untuk Asphalt Mixing Plant. Hasil pembakaran limbah cangkang kelapa sawit berupa abu kerak boiler, merupakan limbah yang memiliki unsur kimia $\mathrm{SiO} 2, \mathrm{Al} 2 \mathrm{O} 3$, dan $\mathrm{CaO}$, dengan kandungan senyawa tersebut dapat berpengaruh dalam kekuatan beton dan mampu meningkatkan kekuatannya. Pada penelitian ini, mutu campuran beton yang direncanakan pada umur 28 hari adalah sebesar $23 \mathrm{MPa}$. Pengujian beton meliputi uji kuat tekan yang dilakukan pada umur 3 hari, 7 hari, 14 hari, 28 hari, 42 hari, dan 56 hari. Sebelum pembuatan sampel beton, dilakukan pengujian kuat tekan mortar terlebih dahulu dengan memvariasikan kandungan abu kerak boiler sebesar 0\%, 15\%, 25\%, 35\%, dan 50\% agar diperoleh campuran optimum. Berdasarkan hasil analisa kuat tekan mortar diperoleh campuran optimum sebesar $15 \%$ untuk pembuatan beton yang akan dibandingkan dengan beton normal. Kuat tekan beton dengan campuran optimum pada umur 28 hari adalah sebesar 24,44 Mpa melebihi dari kuat tekan rencana 23 Mpa. Beton yang memiliki nilai kuat tekan paling tinggi terjadi pada umur 56 hari adalah beton dengan campuran normal yang kuat tekannya sebesar 34,44 MPa lebih tinggi dibandingkan kuat tekan beton dengan campuran optimum $15 \%$ abu kerak boiler yaitu sebesar $28,51 \mathrm{MPa}$.
\end{abstract}

Kata kunci: limbah cangkang kelapa sawit, pengganti pasir, beton normal 


\section{PENDAHULUAN}

\section{Latar Belakang}

Kalimantan merupakan salah satu pulau dengan hasil produki kelapa sawit terbesar di Indonesia. Berdasarkan data statistik perkebunan Indonesia pada tahun 2015 total luas areal perkebunan kelapa sawit di Kalimantan mencapai 3,47 juta Ha dengan produksi 8,12 juta ton per tahun. Dengan besarnya angka produksi tersebut tentu saja limbah yang dihasilkan juga banyak baik berupa limbah padat atau limbah cair. Limbah padat itu berupa tandan buah segar dan cangkang kelapa sawit. Saat ini limbah padat berupa cangkang kelapa sawit dimanfaatkan sebagai bahan bakar boiler untuk mesin penggilingan minyak sawit. Namun proses pembakaran menyisakan abu cangkang yang dibuang di dekat pabrik dan mengakibatkan penumpukan.

Menurut Epi Prianti dkk (2015) abu kerak boiler cangkang kelapa sawit memiliki unsur kimia $\mathrm{SiO}_{2}$ sebanyak 29,9\%, $\mathrm{Al}_{2} \mathrm{O}_{3}$ sebanyak $1,9 \%$ danCaO $26,9 \%$. Dengan kandungan senyawa tersebut maka abu kerak boiler cangkang kelapa sawit dapat dikatakan memiliki sifat pozzolan memungkinkan untuk dimanfaatkan sebagai bahan pengisi pada pembuatan beton normal. Sebab senyawa silika dalam pembuatan beton dapat berpengaruh dalam kekuatan beton dan mampu meningkatkan kekuatannya. Dalam penelitian ini akan mengkaji tentang pemanfaatan abu kerak boiler hasil pembakaran limbah cangkang kelapa sawit sebagai bahan pengisi pada campuran beton normal. Jika digunakan untuk bahan penganti semen, suatu material haruslah mengandung senyawa kapur dalam jumlah yang relatif besar sebab semen memiliki fungsi sebagai pengikat dikarenakan kandungan kapurnya. Berdasarkan hasil penelitian Martin dkk (2012) yang menggunakan abu kerak boiler cangkang kelapa sawit sebagai penganti sebagian semen menunjukan nilai kuat tekan beton menurun seiring meningkatnya persen abu kerak boiler cangkang yang digunakan dan penurunan terbesar kuat tekan beton terjadi pada beton yang menggunakan 20\% abu kerak boiler cangkang kelapa sawit yaitu sebesar 21,78 MPa atau 40\% dari kuat tekan beton normal.

Hanya sedikit penelitian terkait kadar optimum yang baik dalam pemanfaatan abu kerak boiler cangkang kelapa sawit sebagai bahan pengisi pada campuran beton. Dari penelitian Epi prianti, dkk (2015) abu kerak boiler mampu mengantikan peranan pasir sebagai bahan pengisi dan kuat tekan maksimum mampu diperoleh pada kandungan $25 \%$ yaitu $17,83 \mathrm{MPa}$ dengan peningkatan sebesar $24,16 \%$ dari mutu rencana yang sebesar $14 \mathrm{MPa}$ pada umur beton 28 hari. Akan tetapi karena karakteristik abu kerak boiler cangkang kelapa sawit setiap daerah berbeda, maka besar kadar optimumnya berbeda. Oleh sebab itu dilakukan percobaan dengan cara membuat mortar dengan ariasi abukerak boiler dari 0\%, 15\%, 25\%, 35\%, dan $50 \%$ dan dari hasil uji kuat tekan mortar diperoleh kadar optimum yang akan digunakan untuk campuran beton. Pada penelitian ini beton normal akan dibandingkan dengan beton variasi abu kerak boiler hasil pembakaran limbah cangkang kelapa sawit dengan kadar optimum.

Menurut Kardiyono (1996) pemakaian pozzolan dapat mengurangi panas hidrasi maka reaksi yang pengikatan berlangsung lambat sehingga waktu yang dibutuhkan untuk mencapai kekuatan beton yang direncanakan lebih lama. Sehingga dalam penelitian ini beton akan diuji pada umur 3 hari, 7 hari, 14 hari, 28 hari, 42 hari, dan 56 hari dengan perencanaan mutu beton stuktural tahan gempa $\left(f_{c}{ }^{\prime}>20 \mathrm{MPa}\right)$. Hasil dari pengujian akan dianalisa agar dapat diketahui bahwa abu kerak boiler hasil pembakaran limbah cangkang kelapa sawit dapat digunakan pada campuran beton normal menggantikan peranan pasir sebagai bahan pengisi.

\section{Perumusan Masalah}

Beberapa permasalahan yang akan dibahas pada penelitian ini, yakni:

1. Berapa kadar optimum abu kerak boiler yang dapat digunakan sebagai penganti

pasir pada pencampuran beton berdasarkan analisa kuat tekan mortar?

2. Bagaimana perubahan nilai kuat tekan beton normal dan beton variasi abu kerak boiler dengan kadar optimum pengganti pasir?

3. Bagaimana perubahan nilai kuat tekan beton pada umur 3 hari, 7 hari, 14 hari, 28 hari, 42 hari, dan 56 hari?

\subsection{Tujuan Penelitian}

Penelitian ini dilaksanakan dengan tujuan:

1. Mengetahui kadar optimum abu kerak boiler yang dapat digunakan sebagai penganti pasir pada pencampuran beton berdasarkan analisa kuat tekan mortar. 
Pemanfaatan Hasil Pembakaran Limbah Cangkang Kelapa Sawit ...Fauzi Rahman ${ }^{(1)}$, Fathurrahman ${ }^{(2)}$

2. Mengetahui perubahan nilai kuat tekan beton normal dan beton variasi abu kerak boiler dengan kadar optimum pengganti pasir.

3. Mengetahui perubahan nilai kuat tekan beton pada umur 3 hari, 7 hari, 14 hari, 28 hari, 42 hari, dan 56 hari.

\section{Manfaat Penelitian}

Dari hasil penelitian ini dapat memberikan manfaat sebagai berikut:

1. Dapat mengatasi permasalahan pembuangan abu kerak boiler dari hasil pembakaran limbah cangkang kelapa sawit.

2. Mendapatkan beton dengan kekuatan yang baik dan ramah lingkungan.

3. Mendapatkan beton dengan campuran optimum abu kerak boiler sebagai pengganti pasir.

\section{TINJAUAN PUSTAKA}

\section{Beton}

Beton didefinisikan sebagai campuran antara semen Portland atau semen hidraulik yang lain, agregat halus, agregat kasar dan air dengan atau tanpa bahan tambah membentuk massa padat (SNI 032834-2000).

Beton merupakan satu kesatuan yang homogen. Beton ini didapatkan dengan cara mencampurkan agregat halus, agregat kasar, semen portland dan air. Semen, Agregat halus dan Agregat kasar di campur secara bersamaan hingga merata, lalu di tambahkan air sesuai perencanaan, senyawasenyawa silikat dan aluminat dalam semen menyebabkan terjadinya reaksi dengan air. Akibatnya terbentuk suatu senyawa hidrat sebagai produk dari proses hidrasi yang selanjutnya akan terjadi pengerasan beton.

Kekuatan beton adalah gabungan dari interaksi masing-masing bahan pembentuk beton tersebut. Kuat tekan beton mengidentifikasikan mutu dari sebuah struktur. Semakin tinggi tingkat kekuatan struktur yang dikehendaki, semakin tinggi pula mutu beton yang dihasilkan. Ada empat bagian utama yang mempengaruhi mutu dari kekuatan beton tersebut, yaitu proporsi bahan-bahan penyusunnya, metode perancangan, perawatan, dan keadaan pada saat pengecoran dilaksanakan, yang terutama dipengaruhi oleh lingkungan setempat.
Menurut Metha (1986) beton dapat dibedakan berdasarkan berat isi beton dan kuat tekan beton. Terhadap isi beton dapat diklasifikasikan pada tiga kategori umum yaitu:

1. Beton Ringan (Light Weight Concrete/LWC) Beton ringan mempunyai berat $1800 \mathrm{~kg} / \mathrm{m}^{3}$ Pada beton ini terdapat banyak sekali agregat yang diterapkan misalnya agregat sintesis (agregat alam) yang diproses atau dibentuk sehingga berubah karakteristik mekanisnya.

2. Beton Normal (Normal Weight Concrete) Beton yang mempunyai berat $2400 \mathrm{~kg} / \mathrm{m}^{3}$ dan mengandung pasir, kerikil alam dan batu pecah sebagai agregat.

3. Beton Berat (Heavy Weight Concrete)

Beton ini selalu digunakan sebagai pelindung terhadap radiasi yang beratnya $>3200 \mathrm{~kg} / \mathrm{m}^{3}$

\section{Beton Normal}

Berdasarkan SNI 03-2834-2002, beton normal adalah adalah beton yang mempunyai berat isi $\left(2200-2500 \mathrm{~kg} / \mathrm{m}^{3}\right)$ menggunakan agregat alam yang dipecah. Beton normal haruslah menggunakan bahan agregat normal dan tanpa bahan tambah.

Kuat tekan beton normal yang disyaratkan $\mathrm{f} c$ adalah kuat tekan yang ditetapkan oleh perencana struktur (berdasarkan benda uji berbentuk silinder diameter $150 \mathrm{~mm}$, tinggi $300 \mathrm{~mm}$ ), kuat tekan beton yang ditargetkan for adalah kuat tekan rata rata yang diharapkan dapat dicapai yang lebih besar dari f'c.

Pemilihan proporsi campuran beton harus dilaksanakan sebagai berikut:

1) rencana campuran beton ditentukan berdasarkan hubungan antara kuat tekan dan faktor air semen;

2) untuk beton dengan nilai f'c lebih dari $20 \mathrm{MPa}$ proporsi campuran coba serta pelaksanaan produksinya harus didasarkan pada perbandingan berat bahan;

3) untuk beton dengan nilai f'c hingga $20 \mathrm{MPa}$ pelaksanaan produksinya boleh menggunakan perbandingan volume. Perbandingan volume bahan ini harus didasarkan pada perencanaan proporsi campuran dalam berat yang dikonversikan ke dalam volume melalui berat isi rata-rata antara gembur dan padat dari masing-masing bahan. 
Pemanfaatan Hasil Pembakaran Limbah Cangkang Kelapa Sawit ...Fauzi Rahman ${ }^{(1)}$, Fathurrahman ${ }^{(2)}$

\section{Komponen Dalam Campuran Beton}

\section{Semen Portland Pozzolan}

Menurut SNI 15-0302-2004, semen portland pozzoland adalah suatu semen hidrolis yang terdiri dari campuran yang homogen antara semen Portland dengan pozolan halus, yang diproduksi dengan menggiling klinker semen danpozolan bersama-sama, atau mencampur secara merata bubuk semen portland dengan bubuk pozolan, atau gabungan antara menggiling dan mencampur, dimana kadar pozolan 6\% sampai dengan $40 \%$ massa semen portland pozolan.

Dalam semen pada dasarnya ada 4 senyawa penting, yaitu:

a) Trikalsium silikat $\left(\mathrm{C}_{3} \mathrm{~S}\right)$

b) Dikalsium silikat $\left(\mathrm{C}_{2} \mathrm{~S}\right)$

c) Trikalsium aluminat $\left(\mathrm{C}_{3} \mathrm{~A}\right)$

d) Tetrakalsium aluminoferit $\left(\mathrm{C}_{4} \mathrm{AF}\right)$

\section{Agregat Kasar}

Agregat kasar dapat berupa kerikil, pecahan kerikil, batu pecah, terak tanur tiup atau beton semen hidrolis yang dipecah. Sesuai dengan SNI2847-2002, bahwa agregat kasar merupakan agregat yang mempunyai ukuran butir antara 5,00 mm sampai $40 \mathrm{~mm}$.

\section{Agregat Halus}

Agregat halus dapat berupa pasir alam, pasir hasil olahan atau gabungan dari kedua pasir tersebut. Sesuai dengan SNI 03 - 2847 - 2002, bahwa agregat halus merupakan agregat yang mempunyai ukuran butir maksimum sebesar 5,00 mm. Agregat halus tidak boleh mengandung bagian yang lolos lebih dari $45 \%$ pada suatu ukuran ayakan dan tertahan pada ayakan berikutnya.

\section{Air}

Berdasarkan aturan SNI 03-2847-2002 terdapat aturan air sebagai bahan campuran dalam membuat beton. Persyaratan tersebut sebagai berikut:

1. Air yang digunakan pada campuran beton harus bersih dan bebas dari bahan-bahan merusak yang mengandung oli, asam, alkali, garam, bahan organik, atau bahan-bahan lainnya yang merugikan terhadap beton atau tulangan.
2. Air pencampur yang digunakan pada beton prategang atau pada beton yang di dalamnya tertanam logam aluminium, termasuk air bebas yang terkandung dalam agregat, tidak boleh mengandung ion klorida dalam jumlah yang membahayakan.

3. Air yang tidak dapat diminum tidak boleh digunakan pada beton, kecuali ketentuan berikut terpenuhi:

4. Pemilihan proporsi campuran beton harus didasarkan pada campuran beton yang menggunakan air dari sumber yang sama.

\section{Bahan Pozzolan}

Pozzolan yaitu bahan yang mengandung senyawa silika dan Alumina dimana bahan pozzolan itu sendiri tidak mempunyai sifat seperti semen, akan tetapi dengan bentuknya yang halus dan dengan adanya air, maka senyawa-senyawa tersebut akan bereaksi secara kimiawi dengan Kalsium hidroksida (senyawa hasil reaksi antara semen dan air) pada suhu kamar membentuk senyawa Kalsium Aluminat Hidrat yang mempunyai sifat seperti semen.

\section{Bahan Pozzolan terbagi 2 yaitu :}

a. Pozzolan Alam (Natural) : Tufa, abu vulkanis dan tanah Diatomae. Di Indonesia Pozzolan alam dikenal dengan nama Trass.

b. Pozzolan Buatan (sintetis): yang termasuk dalam jenis ini adalah hasil pembakaran tanah liat dan hasil pembakaran batu bara (Fly Ash)

Mineral pembantu yang digunakan umumnya mempunyai komponen aktif yang bersifat pozzolanik (disebut juga mineral pozzolan). Pozzolan adalah bahan alam atau buatan yang sebagaian besar terdiri dari unsur-unsur silikat dan aluminat yang reaktif (Persyaratan Umum Bahan Bangunan di Indonesia, PUBI-1982). Pozzolan sendiri tidak memiliki sifat semen, tetapi dalam keadaan halus (lolos ayakan 0,21 mm) bereaksi dengan air dan kapur padam pada suhu normal 24$27^{\circ} \mathrm{C}$ menjadi suatu massa padat yang tidak larut dalam air.

Menurut Neville (1998), sifat pozzolan adalah sifat yang dimiliki bahan-bahan yang mengandung senyawa silika dan alumina. Sebenarnya bahan tersebut tidak memiliki sifat seperti semen. Namun apabila bahan tersebut 
Pemanfaatan Hasil Pembakaran Limbah Cangkang Kelapa Sawit ...Fauzi Rahman ${ }^{(1)}$, Fathurrahman ${ }^{(2)}$

digiling hingga halus dan dicampur dengan klinker di finish mill untuk membentuk semen dan kemudian semen tersebut bereaksi dengan air maka akan membentuk senyawa CSH dan CAH. Sehingga bahan pozzolan tersebut akan mempunyai sifat seperti semen. Reaksinya yaitu senyawa silika dan alumina akan mengikat senyawa $\mathrm{Ca}(\mathrm{OH})_{2}$ untuk membentuk senyawa CSH dan CAH :

$\mathrm{C}_{3} \mathrm{~S}+\mathrm{H}_{2} \mathrm{O}==>\mathrm{CSH}$ dan $\mathrm{Ca}(\mathrm{OH})_{2}$

$\mathrm{C}_{2} \mathrm{~S}+\mathrm{H}_{2} \mathrm{O}==>\mathrm{CSH}$ dan $\mathrm{Ca}(\mathrm{OH})_{2}$

$\mathrm{Ca}(\mathrm{OH})_{2}+\mathrm{H}_{2} \mathrm{O}+\mathrm{SiO}_{2}==>\mathrm{CSH}$

$\mathrm{Ca}(\mathrm{OH})_{2}+\mathrm{H}_{2} \mathrm{O}+\mathrm{Al}_{2} \mathrm{O}_{3}==\mathrm{CAH}$

Pozzolan dapat dipakai sebagai bahan tambah atau pengganti sebagai semen portland. Bila pozzolan dipakai sebagai bahan tambah akan menjadikan beton lebih mudah diaduk, lebih rapat air, dan lebih tahan terhadap serangan kimia. Beberapa pozzolan dapat mengurangi pemuaian akibat proses reaksi alkali-agregat (reaksi alkali dalam semen dengan silika dalam agregat), dengan demikian mengurangi retak-retak beton akibat reaksi tersebut. Pada pembuatan beton massa pemakaian pozzolan sangat menguntungkan karena menghemat semen, dan mengurangi panas hidrasi (Kardiyono, 1996).

Bahan pozzolan yang digunakan pada penelitian Abu Kerak Boiler Hasil Pembakaran Cangkang Kelapa Sawit merupakan Pozzolan buatan yang berasal dari kerak boiler yang mengalami proses penggilingan atau yang telah dihaluskan. Salah satu limbah boiler ini pada dasarnya adalah abu yang mengeras pada setiap dinding dinding boiler akibat endapan-endapan abu yang terperangkap pada mesin siklon saat terjadinya pembakaran cangkang dan serat buah kelapa sawit pada tungku pembakaran boiler.

Karakterisasi awal terhadap abu kerak boiler bertujuan untuk mengetahui karakteristik abu sehingga dapat dipakai sebagai perbandingan kualitas pasir yang diujikan. Tabel 1 menunjukkan kandungan $\mathrm{SiO}_{2}, \mathrm{Al}_{2} \mathrm{O}_{3}$, dan $\mathrm{CaO}$ yang terkandung pada abu kerak boiler yang diperlukan dalam pembuatan beton. Abu kerak boiler dapat digunakan sebagai bahan pengganti pasir dalam pembuatan beton karena memiliki senyawa yang berperan dalam pembuatan beton.
Tabel 1. Kandungan senyawa utama pada abu kerak boiler

\begin{tabular}{cc}
\hline Senyawa & Kandungan $(\%)$ \\
\hline $\mathrm{SiO}_{2}$ & 29,9 \\
$\mathrm{Al}_{2} \mathrm{O}_{3}$ & 1,9 \\
$\mathrm{CaO}$ & 26,9 \\
\hline
\end{tabular}

$\mathrm{SiO}_{2}$ dalam abu merupakan senyawa dengan kandungan terbesar dibanding komponen utama yang lain, sehingga dapat difungsikan sebagai pengganti pasir untuk pengisi pada pembuatan beton. Pasir dengan kandungan $\mathrm{SiO}_{2}$ yang besar dapat digunakan sebagai pengikat.

Tabel 2. Pengujian mutu abu kerak boiler bebagai agregat halus

\begin{tabular}{lccc}
\hline \multicolumn{1}{c}{ Parameter } & Satuan & Hasil & Persyaratan \\
\hline Fine & $\%$ & 3,65 & $2,3-3,1$ \\
Modulus & $\mathrm{g} / \mathrm{cm}^{3}$ & 2,11 & $>2,5$ \\
Massa Jenis & $\%$ & 3,6 & $<5 \%$ \\
Kadar & $\%$ & 0,28 & $<1 \%$ \\
Lumpur & & & \\
Penyerapan & & & \\
air & & & \\
\hline
\end{tabular}

Fine modulus yang dihasilkan abu lebih besar $0,54 \%$, dari syarat batas maksimum fine modulus agregat. Fine modulus kurang dari 2,3\% dapat dikategorikan sebagai lumpur dan diatas standar 3,1\% dapat dikategorikan sebagai agregat kasar. Hasil massa jenis abu sebesar $2,11 \mathrm{~g} / \mathrm{cm}^{3}$, lebih rendah dari massa jenis yang dimiliki pasir. Menurut ASTM C128-93, massa jenis yang baik untuk pembuatan beton di atas 2,50\% sehingga termasuk agregat kasar.

Pada penelitian Epi Prianti (2015) diperoleh penyerapan air pada abu sebesar $0,28 \%$. Nilai penyerapan air yang dihasilkan abu kerak boiler memenuhi syarat mencegah atau mengurangi rongga kosong dalam beton (Epi dkk, 2015).

\section{Kekuatan Tekan Mortar}

Berdasarkan SNI 03-6825-2002 mortar dapat didefinisikan sebagai campuran antara Agregat halus (pasir), air dan bahan perekat (semen portland) dengan komposisi tertentu.

Berdasarkan SNI 03-6882-2002, Mortar terdiri dari beberapa tipe antara lain : 
Pemanfaatan Hasil Pembakaran Limbah Cangkang Kelapa Sawit ...Fauzi Rahman ${ }^{(1)}$, Fathurrahman ${ }^{(2)}$

1. Mortar tipe $M$ adalah mortar yang mempunyai kekuaten 17,2 $\mathrm{MPa}$

2. Mortar tipe $\mathrm{S}$ adalah mortar yang mempunyai kekuatan 12,5 $\mathrm{MPa}$

3. Mortar tipe $\mathrm{N}$ adalah mortar yang mempunyai kekualan 5,2 $\mathrm{MPa}$

4. Mortar tipe $\mathrm{O}$ adalah mortar yang mempunyai kekuatan 2,4 MPa

Metode pengujian kekuatan tekan mortar dapat menggunakan acuan SNI 03-6825-2002. Pengujian kekuatan mortar semen Portland menggunakan benda uji khusus berbentuk kubus dengan ukuran sisi $5 \mathrm{~cm}$. Kekuatan tekan mortar semen Portland adalah gaya maksimum per satuan luas yang bekerja ada benda uji mortar semen Portland berbentuk kubus dengan ukuran tertentu serta berumur tertentu dan Gaya maksimum merupakan gaya yang bekerja pada saat benda uji kubus pecah.

Rumus-rumus yang dugunakan untuk perhitungan adalah Kekuatan tekan mortar dihitung dengan rumus :

$$
\sigma m=\frac{\text { Pmaks }}{A}
$$

Dimana

$\sigma m=$ kekuatan tekan mortar, $\mathrm{MPa}$

Pmaks = gaya tekan maksimum, $\mathrm{N}$

A = luas penampang benda uji, $\mathrm{mm}^{2}$

\section{Kekuatan Tekan Beton}

Sifat paling penting dari beton pada umumnya ialah kuat tekan. Kuat tekan beton biasanya berhubungan dengan sifat-sifat lain, maksudnya bila kuat tekannya tinggi sifat-sifat yang lain juga baik. Pengukuran kuat tekan beton dilakukan dengan membuat benda uji berupa kubus beton dengan ukuran $150 \mathrm{~mm}$ atau silinder beton dengan diameter $150 \mathrm{~mm}$ dan tinggi $300 \mathrm{~mm}$. Kedua benda uji ditekan dengan alat uji tekan sampai pecah. Beban tekan maksimum yang memecahkan itu dibagi dengan luas penampang kubus atau luas penampang silinder diperoleh nilai kuat tekan. Nilai diperoleh bahwa kuat tekan beton dengan benda uji silinder menghasilkan kuat tekan sekitar $84 \%$ daripada dengan benda uji kubus.

Kekuatan beton (kuat tekan, kuat tarik, kuat lekat) bertambah tinggi dengan bertambahnya umur. Yang dimaksudkan umur disini dihitung sejak beton dibuat. Kenaikan kekuatan beton mula-mula cepat akan tetapi lama-lama kenaikan itu menjadi makin lambat. Oleh karena itu sebagai standar kekuatan beton dipakai kekuatan beton pada umur 28 hari. Bila karena sesuatu hal diinginkan untuk mengetahui kekuatan pada umur yang kurang dari 28 hari, dapat dilakukan dengan menguji kuat tekan beton pada umur 3 hari misalnya dan hasilnya dikalikan dengan faktor tertentu untuk mendapatkan perkiraan kuat tekan beton umur 28 hari (Pramono, dkk 2008).

Nilai kekuatan tekan beton dapat dihitung dengan persamaan

$$
f_{c}^{\prime}=P / A
$$

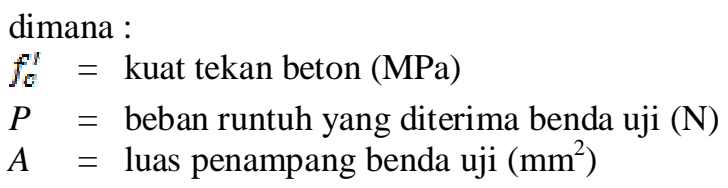

Menurut SNI 03-2847-2002 kuat tekan minimum beton untuk tujuan beton struktural harus tidak boleh kurang dari 17,5 MPa dan Menurut SNI 036468-2000 beton berkekuatan tinggi adalah beton yang memiliki kuat tekan $\mathrm{fc}^{\prime} \geq 41,4 \mathrm{MPa}$.

\section{METODE PENELITIAN}

Metode dan rancangan untuk penelitian ini yaitu:

1. Mortar direncanakan dengan bahan-bahan dasar pembentuk campuran yaitu pasir Barito, yang divariasikan dengan Abu kerak boiler hasil pembakaran limbah cangkang kelapa sawit $0 \%, 15 \%, 25 \%, 35 \%, 50 \%$ dicampur dengan semen portland pozolan tipe 1 semen gresik dan air PDAM.

2. Metode perencanaan campuran mortar menggunakan SNI - 03-6825-2002

3. Untuk uji kekuatan tekan mortar, kubus yang digunakan dengan ukuran sisi $50 \mathrm{~mm}$ dengan variasi mortar yang menggunakan abu kerak boiler $0 \%$ (M0), mortar yang menggunakan abu kerak boiler 15\% (M15), mortar yang menggunakan abu kerak boiler 25\% (M25), mortar yang menggunakan abu kerak boiler $35 \%$ (M35) dan mortar yang menggunakan abu kerak boiler 50\% (M50).

4. Pengujian terhadap kubus untuk kekuatan tekan mortar dilakukan pada umur 3 hari, 7 hari, 14 hari, 21 hari dan 28 hari. 
Pemanfaatan Hasil Pembakaran Limbah Cangkang Kelapa Sawit ...Fauzi Rahman ${ }^{(1)}$, Fathurrahman ${ }^{(2)}$

5. Jumlah benda uji untuk setiap variasi sebanyak 3 sampel uji.

6. Beton direncanakan untuk $f_{c}$ sebesar $23 \mathrm{MPa}$ dengan bahan-bahan dasar pembentuk campuran yaitu pasir Barito, batu Katunun, yang divariasikan dengan abu kerak boiler hasil pembakaran limbah cangkang kelapa sawit, semen portland pozolan tipe 1 semen gresik dan air PDAM.

7. Persentasi abu kerak boiler hasil pembakaran limbah cangkang kelapa sawit yang digunakan dalam campuran beton adalah persentasi paling optimum berdasarkan kekuatan tekan pada pengujian kubus mortar dan persentasi bahan pengganti pasir berdasarkan perbandingan berat bahan.

8. Metode perencanaan campuran beton menggunakan SNI 03-2834-2000 dengan syarat kekuatan berdasarkan SNI 03-2847-2002.

9. Untuk uji kekuatan tekan beton, silinder yang digunakan berdiameter $150 \mathrm{~mm}$ dan tinggi 300 $\mathrm{mm}$ dengan variasi beton yang menggunakan persentasi abu kerak boiler paling optimum

10. Pengujian terhadap silinder untuk kekuatan tekan dilakukan pada umur 3 hari, 7 hari, 14 hari, 28 hari, 42 hari, dan 56 hari.

11. Menurut SNI 2493-2011 jumlah benda uji minimal 3 untuk masing-masing umur pengujian dan kondisi pengujian maka benda uji dalam penelitian ini berjumlah 45 buah dengan menggunakan 3 benda uji untuk setiap variasi.

\section{HASIL DAN PEMBAHASAN}

\section{Hasil Pemeriksaan Bahan}

Pemeriksaan bahan bertujuan untuk mengetahui karakteristik bahan yang akan digunakan dalam pembuatan beton dan untuk menentukan apakah bahan yang digunakan memenuhi syarat. Pemeriksaan bahan ini meliputi pemeriksaan terhadap semen, agregat halus, agregat kasar dan agregat pengganti. Hasil pemeriksaan dapat dilihat pada Tabel 3 sampai dengan Tabel 6 .
Tabel 3. Hasil Pemeriksaan Semen

\begin{tabular}{|c|c|c|c|}
\hline No. & $\begin{array}{c}\text { Jenis } \\
\text { Pemeriksaan }\end{array}$ & $\begin{array}{c}\text { Nilai } \\
\text { Pemeriksaa } \\
n\end{array}$ & $\begin{array}{c}\text { SNI 15- } \\
0302- \\
2004\end{array}$ \\
\hline 1. & Berat Jenis & $3,15 \mathrm{gr} / \mathrm{cm}^{3}$ & \\
\hline 2. & $\begin{array}{l}\text { Konsistensi } \\
\text { Normal }\end{array}$ & $25 \%$ & \\
\hline 3. & $\begin{array}{l}\text { Berat Volume } \\
\text { a.Kondisi } \\
\text { lepas } \\
\text { b.Kondisi } \\
\text { goyangan } \\
\text { c.Kondisi } \\
\text { pemadatan }\end{array}$ & $\begin{array}{l}1,11 \mathrm{gr} / \mathrm{cm}^{3} \\
1,18 \mathrm{gr} / \mathrm{cm}^{3} \\
1,22 \mathrm{gr} / \mathrm{cm}^{3}\end{array}$ & \\
\hline 4. & $\begin{array}{l}\text { Waktu } \\
\text { Pengikatan } \\
\text { a.Awal } \\
\text { b.Akhir }\end{array}$ & (Menit) & $\begin{array}{l}>45 \\
<420\end{array}$ \\
\hline
\end{tabular}

Tabel 4 Hasil Pemeriksaan Agregat Halus

\begin{tabular}{|c|c|c|c|}
\hline No & $\begin{array}{c}\text { Jenis } \\
\text { Pemeriksaan }\end{array}$ & $\begin{array}{c}\text { Nilai } \\
\text { Pemeriksaan }\end{array}$ & $\begin{array}{c}\text { SK } \\
\text { SNI S- } \\
04- \\
1989- \\
\text { F }\end{array}$ \\
\hline 1. & Kadar Air & $3,7 \%$ & \\
\hline 2. & Kadar Lumpur & $0,475 \%$ & $<5 \%$ \\
\hline 3. & Kadar Organik & Warna no. 1 & \\
\hline 4. & $\begin{array}{l}\text { Analisa } \\
\text { Saringan }\end{array}$ & Zona III & \\
\hline 5. & Fine Modulus & 2,31 & $1,5-3,8$ \\
\hline 6. & $\begin{array}{l}\text { Berat Volume } \\
\text { a.Kondisi Lepas } \\
\text { b.Kondisi } \\
\text { Goyangan } \\
\text { c.Kondisi } \\
\text { Pemadatan }\end{array}$ & $\begin{array}{l}1,44 \mathrm{gr} / \mathrm{cm}^{3} \\
1,52 \mathrm{gr} / \mathrm{cm}^{3} \\
1,55 \mathrm{gr} / \mathrm{cm}^{3}\end{array}$ & \\
\hline 7. & $\begin{array}{l}\text { Berat Jenis } \\
\text { a.Apparent } \\
\text { specific } \\
\text { gravity } \\
\text { b.Bulk specific } \\
\quad \text { gravity on dry } \\
\text { basic } \\
\text { c. Bulk specific } \\
\text { gravity on } \\
\text { SSD basic } \\
\text { d. Water } \\
\text { absorbtion } \\
\text { percentage }\end{array}$ & $\begin{array}{l}2,68 \\
2,60\end{array}$ & \\
\hline
\end{tabular}


Pemanfaatan Hasil Pembakaran Limbah Cangkang Kelapa Sawit ...Fauzi Rahman ${ }^{(1)}$, Fathurrahman ${ }^{(2)}$

Tabel 5. Hasil Pemeriksaan Agregat Kasar

\begin{tabular}{|c|c|c|c|}
\hline No & $\begin{array}{c}\text { Jenis } \\
\text { Pemeriksaan }\end{array}$ & $\begin{array}{c}\text { Nilai } \\
\text { Pemeriksaa } \\
n\end{array}$ & $\begin{array}{c}\text { SK SNI } \\
\text { S-04- } \\
1989-F\end{array}$ \\
\hline 1. & Kadar Air & $0,50 \%$ & \\
\hline 2. & Kadar Lumpur & $0,875 \%$ & $<5 \%$ \\
\hline 3. & Abrasi & $10,80 \%$ & \\
\hline 4. & $\begin{array}{l}\text { Analisa } \\
\text { Saringan } \\
\text { (ukuran } \\
\text { maksimun butir) }\end{array}$ & $40 \mathrm{~mm}$ & \\
\hline 5. & Fine Modulus & 7,96 & $6,0-7,1$ \\
\hline 6. & $\begin{array}{l}\text { Berat Volume } \\
\text { a.Kondisi Lepas } \\
\text { b.Kondisi } \\
\text { Goyangan } \\
\text { c.Kondisi } \\
\text { Pemadatan }\end{array}$ & $\begin{array}{l}1,42 \mathrm{gr} / \mathrm{cm}^{3} \\
1,49 \mathrm{gr} / \mathrm{cm}^{3} \\
1,54 \mathrm{gr} / \mathrm{cm}^{3}\end{array}$ & \\
\hline 7. & $\begin{array}{l}\text { Berat Jenis } \\
\text { a.Apparent } \\
\text { specific } \\
\text { gravity } \\
\text { b.Bulk specific } \\
\text { gravity on dry } \\
\text { basic } \\
\text { c.Bulk specific } \\
\text { gravity on } \\
\text { SSD basic } \\
\text { d. Water } \\
\text { absorbtion } \\
\text { percentage }\end{array}$ & $\begin{array}{l}2,96 \\
2,88\end{array}$ & \\
\hline
\end{tabular}

Tabel 6. Hasil Pemeriksaan abu kerak boiler hasil pembakaran limbah cangkang kelapa sawit

\begin{tabular}{|c|c|c|c|}
\hline No. & $\begin{array}{c}\text { Jenis } \\
\text { Pemeriksaan }\end{array}$ & $\begin{array}{c}\text { Nilai } \\
\text { Pemeriksaa } \\
n\end{array}$ & $\begin{array}{c}\text { SK SNI } \\
\text { S-04- } \\
1989-F\end{array}$ \\
\hline 1. & Kadar Air & $24,3 \%$ & \\
\hline 2. & Kadar Lumpur & $14,52 \%$ & $<5 \%$ \\
\hline 3. & Kadar Organik & Warna no. 1 & \\
\hline 4. & $\begin{array}{l}\text { Analisa } \\
\text { Saringan }\end{array}$ & Zona III & \\
\hline 5. & Fine Modulus & 2,05 & $1,5-3,8$ \\
\hline 6. & $\begin{array}{l}\text { Berat Volume } \\
\text { a.Kondisi } \\
\text { Lepas } \\
\text { b.Kondisi } \\
\text { Goyangan } \\
\text { c.Kondisi } \\
\text { Pemadatan }\end{array}$ & $\begin{array}{l}0,39 \mathrm{gr} / \mathrm{cm}^{3} \\
0,45 \mathrm{gr} / \mathrm{cm}^{3} \\
0,47 \mathrm{gr} / \mathrm{cm}^{3}\end{array}$ & \\
\hline
\end{tabular}

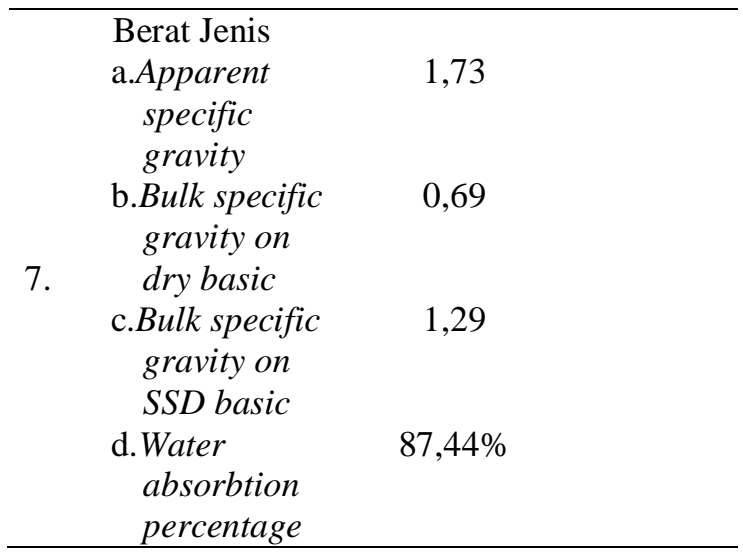

Tabel 7 Hasil Pemeriksaan kimia abu kerak boiler hasil pembakaran limbah cangkang kelapa sawit

\begin{tabular}{clcc}
\hline No. & Komposisi kimia & $\begin{array}{c}\text { Hasil } \\
\text { uji }\end{array}$ & $\begin{array}{c}\text { ASTM } \\
\text { C618-03 } \\
\text { Jenis N }\end{array}$ \\
\hline 1. & $\begin{array}{l}\text { Silicon Oxide } \\
\left(\mathrm{SiO}_{2}\right)\end{array}$ & $29,3 \%$ & $70 \%$ \\
\hline 2. & $\begin{array}{l}\text { Calcium } \\
\text { Carbonate } \\
\left(\text { CaCO }_{3}\right)\end{array}$ & $41,4 \%$ & - \\
\hline & $\begin{array}{l}\text { Manganese(Mn) } \\
+ \text { Iron }(\mathrm{Fe})+ \\
\text { Pohosphorus }(\mathrm{P}) \\
+ \text { Silicon }(\mathrm{Si})\end{array}$ & $29,3 \%$ & - \\
\hline
\end{tabular}

\section{Hasil dan Pembahasan Pengujian Kuat}

\section{Tekan Mortar}

Adapun hasil kuat tekan mortar diatas, diplot dalam bagan yang dapat dilihat pada Gambar 1 sebagai berikut:

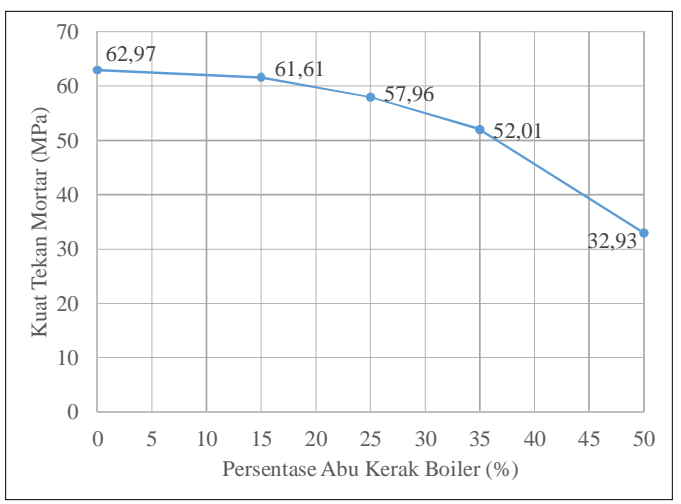

Gambar 1 Hasil kuat tekan mortar rata-rata pada umur 28 hari 
Dari Gambar 1 pada umur 28 hari, mortar dengan kadar abu kerak boiler $15 \%$ kuat tekannya sebesar 61,61 MPa, kekuatannya menurun 2,16\% jika dibandingkan dengan kuat tekan mortar normal sebesar 62,97 MPa. Untuk mortar dengan kadar abu kerak boiler $25 \%$ kuat tekannya sebesar 57,96 $\mathrm{MPa}$ kekuatannya menurun $7,95 \%$ dan untuk mortar dengan kadar abu kerak boiler 35\% kuat tekannya sebesar 52,01 MPa kekuatannya menurun 17,39\%. Begitu juga mortar dengan kadar abu kerak boiler $50 \%$ kuat tekannya sebesar 32,93 MPa kekuatannya menurun $47,70 \%$.

Berdasarkan analisa kuat tekan mortar semakin besar kadar abu kerak boiler maka semakin menurun kekuatan tekannya. Kadar abu kerak boiler yang akan digunakan pada campuran beton adalah sebesar $15 \%$ karena memiliki nilai kuat tekan tertinggi, yang kemudian akan dibandingkan dengan beton normal.

\section{Hasil dan Pembahasan Pengujian Kuat}

\section{Tekan Beton}

Untuk sampel, persentasi abu kerak boiler hasil pembakaran limbah cangkang kelapa sawit yang digunakan sebagai pengganti pasir pada campuran beton adalah $0 \%$ (AKB1) dan persentasi optimum yaitu $15 \%$ (AKB2). Kuat tekan rata-rata yang direncanakan adalah sebesar $23 \mathrm{MPa}$.

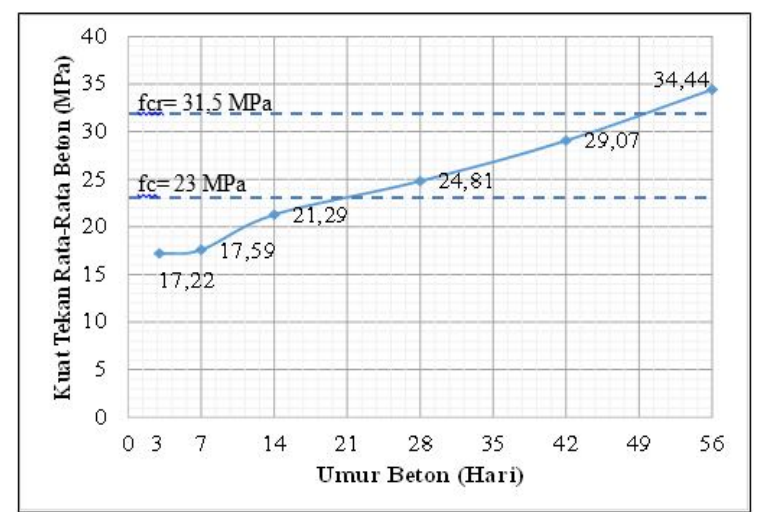

Gambar 2 Grafik Hubungan Kuat Tekan Beton AKB1 dengan Umur Beton

Pada Gambar 2 menunjukan bahwa semakin meningkatnya umur beton maka semakin meningkat pula kekuatan tekannya. Untuk umur beton 3 hari kuat tekan rata-ratanya sebesar 17,22 MPa dan pada umur beton 7 hari kuat tekan rataratanya sebesar 17,59 $\mathrm{MPa}$. Begitu juga pada umur
14 hari kuat tekan rata-ratanya sebesar 21,29 MPa. Pada umur 28 hari, beton AKB1 menunjukan kekuatan tekan rata-rata sebesar $24,81 \mathrm{MPa}$ atau $7,86 \%$ lebih besar dari kuat tekan rata-rata yang disyaratkan yaitu $23 \mathrm{MPa}$. Sedangkan beton pada umur diatas 28 hari yaitu beton dengan umur 42 hari kuat tekan rata-ratanya sebesar 29,07 MPa dan beton dengan umur 56 hari kuat tekan rata-ratanya sebesar 34,44 MPa.

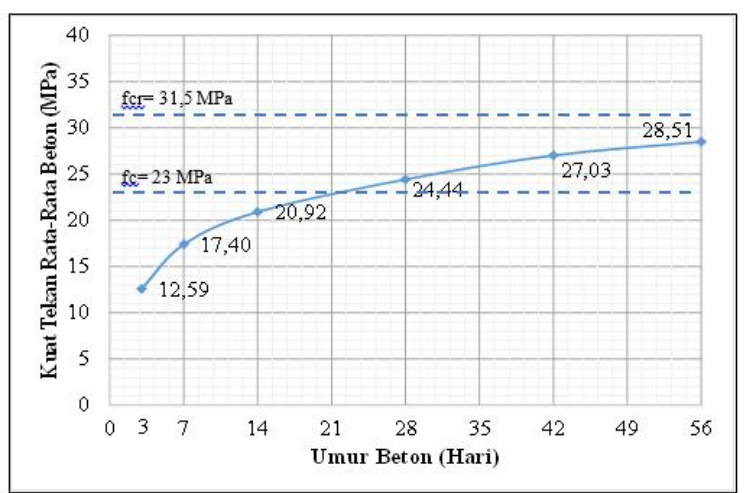

Gambar 3 Grafik Hubungan Kuat Tekan Beton AKB2 dengan Umur Beton

Dari Gambar 3 menunjukan bahwa semakin meningkatnya umur beton maka semakin meningkat pula kekuatan tekannya. Untuk umur beton 3 hari kuat tekan rata-ratanya sebesar 12,59 MPa dan pada umur beton 7 hari kuat tekan rataratanya sebesar 17,40 MPa. Begitu juga pada umur 14 hari kuat tekan rata-ratanya sebesar 20,92 MPa. Pada umur 28 hari, beton AKB2 menunjukan kekuatan tekan rata-rata sebesar $24,44 \mathrm{MPa}$ atau $6,25 \%$ lebih besar dari kuat tekan rata-rata yang disyaratkan yaitu $23 \mathrm{MPa}$. Sedangkan beton pada umur diatas 28 hari yaitu beton dengan umur 42 hari kuat tekan rata-ratanya sebesar 27,03 $\mathrm{MPa}$ dan beton dengan umur 56 hari kuat tekan rata-ratanya sebesar 28,51 MPa.

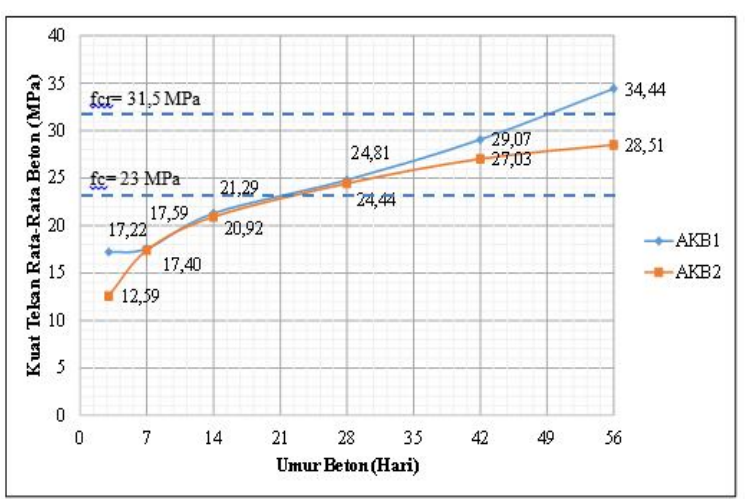

Gambar 4 Perbandingan hasil pengujian kuat tekan beton AKB1 dan beton AKB2 
Dilihat dari Gambar 4 jika kuat tekan ratarata beton AKB2 dibandingkan dengan kuat tekan rata-rata beton AKB1 maka pada umur 3 hari kuat tekan rata-ratanya mengalami penurunan sebesar 4,628 MPa sedangkan pada umur 7 hari kuat tekan rata-ratanya menurun sebesar $0,185 \mathrm{MPa}$. Begitu pula pada umur 14 hari kuat tekan rata-ratanya menurun sebesar 0,370 MPa dan pada umur 28 hari kuat tekan rata-ratanya menurun sebesar 0,370 $\mathrm{MPa}$. Untuk umur 42 hari kuat tekan rata-ratanya menurun sebesar 2,037 MPa dan pada umur 56 hari kuat tekan rata-ratanya menurun sebesar 5,924 MPa.

Berdasarkan hasil analisa tersebut maka beton dengan campuran $85 \%$ pasir barito dan $15 \%$ abu kerak boiler hasil pembakaran limbah cangkang kelapa sawit mengakibatkan penurunan kekuatan tekan. Walaupun setelah umur beton 28 hari, kuat tekannya tidak lebih besar dari kuat tekan beton normal akan tetapi mampu mencapai kuat tekan rencana sebesar $23 \mathrm{MPa}$ pada umur 28 hari. Hal ini karena abu kerak boiler hasil pembakaran limbah cangkang kelapa sawit masih memiliki karakter seperti agregat halus. Berdasarkan hasil pemeriksaan saringan agregat halus, abu kerak boiler masuk kedalam zona 3 dengan kata lain bisa dikombinasikan dengan pasir barito sebagai agregat halus pada campuran beton.

\section{KESIMPULAN DAN SARAN}

\section{Kesimpulan}

Dari hasil penelitian mengenai pemanfaatan hasil pembakaran limbah cangkang kelapa sawit sebagai penggnati pasir pada pembuatan beton normal dapat ditarik kesimpulan sebagai berikut:

1. Kadar optimum abu kerak boiler hasil pembakaran limbah cangkang kelapa sawit yang dapat digunakan sebagai penganti pasir pada pencampuran beton adalah sebesar $15 \%$.

2. Perubahan nilai kuat tekan beton normal dan beton dengan campuran optimum pada umur 3 hari, 7 hari, 14 hari, 28 hari, 42 hari, dan 56 hari adalah semakin meningkat kuat tekannya seiring dengan semakin bertambahnya umur beton.

3. Abu kerak boiler hasil pembakaran limbah cangkang kelapa sawit sebesar $15 \%$ dapat digunakan sebagai pengganti agregat halus (pasir) pada campuran beton dengan kuat tekan rata-rata sebesar 24,44 Mpa melebihi kuat tekan yang direncanakan 23 Mpa pada umur 28 hari.

4. Nilai kuat tekan terbesar diperoleh pada umur 56 hari. Untuk beton normal kuat tekannya sebesar 34,44 MPa lebih tinggi dari pada kuat tekan beton dengan campuran optimum yang sebesar 28,51 MPa.

\subsection{Saran}

Adapun saran yang dapat diberikan terkait penelitian hasil pembakaran limbah cangkang kelapa sawit sebagai bahan pengganti pasir pada pembuatan beton normal adalah sebagai berikut:

1. Dapat dilakukan penelitian lanjutan mengenai pengaruh abu kerak boiler hasil pembakaran limbah cangkang kelapa sawit terhadap nilai kuat tekan beton dengan persentase kurang dari $15 \%$.

2. Dapat dilakukan penelitian mengenai pemanfaatan abu kerak boiler hasil pembakaran limbah cangkang kelapa sawit selain sebagai bahan pengganti pasir pada campuran beton.

Dapat dilakukan penelitian mengenai pemanfaatan abu kerak boiler hasil pembakaran limbah cangkang kelapa sawit sebagai filler lapis pondasi semen pondasi bawah.

\section{DAFTAR PUSTAKA}

ASTM C 469-02, Test Method for Static Modulus of Elasticity and Poisson's Ratio of Concrete in Compression, Annual Books of ASTM Standards, USA.

ASTM C 618-03. 2003. Standard Specification for Pozzoland and Raw or Calcined Natural Pozzolan for Use in Concrete. United States : Association of Standard Testing Materials.

Badan Standardisasi Nasional. (2000). Tata cara pembuatan rencana campuran beton normal. Jakarta.

Badan Standardisasi Nasional. (2002). Metode pengujian kekuatan tekan mortar semen Portland untuk pekerjaan sipil. Jakarta

Badan Standardisasi Nasional. (2002). Spesifikasi mortar untuk pekerjaan pasangan. Jakarta 
Pemanfaatan Hasil Pembakaran Limbah Cangkang Kelapa Sawit ...Fauzi Rahman ${ }^{(1)}$, Fathurrahman ${ }^{(2)}$

Badan Standardisasi Nasional. (2002). Tata Cara Perhitungan Struktur Beton Untuk Bangunan Gedung. Jakarta.

Badan Standardisasi Nasional. (2004). Semen Portland. Jakarta.

Badan Standardisasi Nasional. (2011). Tata Cara Pembuatan dan Perawatan Benda Uji di Laboratorium. Jakarta.

Direktorat Penyelidikan Masalah Bangunan. (1982). Persyaratan Umum Bahan Bangunan di Indonesia. Jakarta.

Martin dkk. (2012). Perilaku Kuat Tekan Beton Dengan Abu Cangkang Sawit Sebagai Pengganti Sebagian Semen. Bengkulu.

Menteri Perindustrian Republik Indonesia (1980). Mutu dan Cara Uji Agregat Beton. Jakarta.

Metha, P. Kumar (1986). Concrete: Structure, Properties and Materials. University of California.

Murdock, LJ. K M Brook (1979). Bahan dan Praktek Beton. Erlangga. Jakarta.

Neville, AM. (1998) Properties of Concrete. England.

Nugraha, Paul dan Anthoni (2007). Teknologi beton. Andi. Yogyakarta.

Susilorini, Retno. Kusno Adi Sambowo. (2011). Teknologi Beton Lanjutan Durabilitas Beton Edisi Ke-2. Penerbit Surya Perdana Semesta. Semarang.

Prianti, Epi. et al. (2015). Pemanfaatan Abu Kerak Boiler Hasil Pembakaran Limbah Kelapa Sawit Sebagai Pengganti Parsial Pasir Pada Pembuatan Beton. POSITRON. Volume V, No. 1.

Pramono, Didiek. Suryadi H.S. (2008). Bahan Konstruksi Teknik. Penerbit Gunadarma. Jakarta.

Samekto, W. Candra Rahmadiyanto (2001). Teknologi Beton. Yogyakarta.

Rahman, Fauzi. (2006). Pengaruh Kehalusan Serbuk Pasir Silika Terhadap Kekuatan
Tekan Mortar. Universitas Lambung Mangkurat. Banjarmasin.

Tjokrodimuljo, Kardiyono. (2007). Teknologi Beton. Biro Penerbit KMTS FT UGM. Yogyakarta

Wardhana, Henry. Ninis Hadi Haryanti. (2001). Studi Abu Dasar Batubara Sebagai Bahan Konstruksi Campuran Beton.Universitas Lambung Mangkurat. Banjarmasin.

Wang, C. K., dan Salmon, C. G., 1994, Disain Beton Bertulang, Edisi Keempat. Jakarta : Penerbit Erlangga.

Yuzika .dkk. (2015). Optimasi Tingkat Kemurnian Silika, $\mathrm{SiO}_{2}$, Dari Abu Cangkang Sawit Berdasarkan Konsentrasi Pengasaman. Pontianak 